\title{
Beyond exceptionalism:
}

\section{notes on Michel-Rolph Trouillot's}

\section{"The odd and the ordinary"}

\author{
Rodrigo C. Bulamah \\ Júlia Vilaça Goyatá ${ }^{2}$ \\ Bethânia Pereira ${ }^{3}$
}

'Universidade Federal de São Paulo (Unifesp), Programa de Pós-graduação em Ciências Sociais, São Paulo/SP, Brasil

${ }^{2}$ Universidade Federal do Maranhão (UFMA), Departamento de Sociologia e Antropologia, São Luis/MA, Brasil

3 Universidade Estadual de Campinas (Unicamp), Programa de Pós-graduação em História, Campinas/SP, Brasil

Originally published in 1990, in the third issue of the journal Cimarrón: New Perspectives on the Caribbean, the article by Michel-Rolph Trouillot (1949-2012), The odd and the ordinary: Haiti, the Caribbean, and the World was written by the Haitian anthropologist in a paradigmatic moment in the history of his native country and his academic trajectory. ${ }^{1}$ Since 1986 , after the long and violent period of the Duvalier dictatorship, democratic initiatives took shape and new progressive political debates emerged in Haiti. ${ }^{2}$ At this time, Trouillot, who had left Haiti in 1968, precisely because of political persecution, was establishing himself in the North Atlantic as a researcher and university professor. ${ }^{3}$ Trouillot taught at Duke University, beginning in 1983 , and for the next five years helped create the Caribbean Studies Program there (Woodson \& Williams, 2013). Shortly after finishing his Ph.D. in the Atlantic History and Culture Program at Johns Hopkins University in 1985, he became a professor at this institution, where he remained until 1998, when he was hired by the prestigious Department of Anthropology at the University of Chicago, where he taught for the rest of his life. ${ }^{4}$

\footnotetext{
1 The journal Cimarrón: New Perspectives on the Caribbean was created in 1985, linked to the Association os Caribbean Studies, at the City University of New York (CUNY). It aimed to fill the gap in US intellectual production on the Caribbean. The editor of the first edition, Basil Wilson, was a member of the John Jay College Department of African American Studies. Since the first issue, the journal has privileged work by Caribbean intellectuals and writers (Goldway, 1986).

2 Jean-Claude Duvalier, Baby Doc, was overthrown in 1986 through a joint civil society movement, articulated with the Catholic Church and supported by the Haitian diaspora and various international actors, ending a 29-year regime. Imposed by his father, François Duvalier (1907-1991), Papa Doc, a few years after his election in 1957, the Duvalierist dictatorship and its authoritarian mechanisms were also object of Trouillot's sociological, anthropological and historiographical interest. The author developed the theme in the book Haiti, State against Nation: The Origins and Legacy of Duvalierism, published in 1990 concomitantly with the article we present here, exerting a strong influence on later works. See, for instance, Dubois (2012), Hector \& Hurbon (2009); Andrade (2019).

3 It is important to note that Trouillot belongs to a family of Haitian intellectuals, which, as he writes in the first line of the preface to his book Silencing the Past: Power and the Production of History (1995) was particularly interested in history: "I grew up in a family where history sat at the dinner table" (1995, p. 15). His father, Ernest Trouillot (1922-1987), was a lawyer, teacher and even host of a television program about Haitian history. His paternal uncle, Henock Trouillot (1923-1988), was a renowned historian and for many years head of Haiti's National Archives. For more details on Trouillot's biography see: Woodson, (s / d; 2013); Bonilla (2014).

4 Trouillot died in Chicago at age 61 from a brain aneurysm. His obituaries show the extent of his contribution to the social sciences, from Caribbean studies to anthropological theory: Scott (2012); Woodson \& Williams (2013); Price (2013); Dubois (2013).
} 
The odd and the ordinary is thus part of a series of works published by Trouillot since the 199os. Not by chance, this was when the author began to reflect more systematically on contemporary Haiti. It followed at least a decade of studies dedicated to understanding the colonial history of Saint Domingue - ranging from important academic articles written in English (Trouillot, 1981, 1982) to an early work published in Haitian Creole, a language that all Haitians speak, which was a pioneering political effort to tell the history of the Haitian Revolution through the prism of historical materialism to a Creole speaking audience (Trouillot, 2012 [1977]). He also conducted important ethnographic fieldwork on the island of Dominica, a study that became his doctoral thesis (Trouillot, 1988). Starting with the publication of Les Racines Historiques de l'État Duvaliérien (1986) - which four years later, and with some adaptations, became the classic Haiti, State Against Nation: The Origins and Legacy of Duvalierism (199ob) - he offered systematic reflections on Haitian political history, its relationship with the Caribbean and global capitalism, and, ultimately, on Haiti's position in the Western anthropological imaginary.

Without putting aside comparative approaches, it was from these empirical materials that Trouillot developed groundbreaking analyses on post-plantation contexts: from the historical autonomy of the state in post-colonial contexts and the formation of authoritarian rhetoric (Trouillot, 199ob; 1992 ) to creolization and sociogenesis processes in regions that we can identify today as part of the geography of the African diaspora (Trouillot, 1990a; 2006). Two other studies by the author recently translated into Portuguese are fundamental examples of his work in the 199os: the article "The Caribbean region: an open frontier in anthropological theory" ([1992] 2018), dedicated to understanding the construction of the Caribbean as an ethnographic region and anthropological object, and the book Silencing the Past: Power and the Production of History ([1995] 2016), in which he discusses how the production of history, through both social practices and narratives, is shaped by situated power relations. ${ }^{5}$

Specifically in The odd and the ordinary, Trouillot reflected in a manner similar to what Edward Said (1935-2003) had done years earlier with Orientalism (1990 [1978]), in which the Palestinian author pointed to the construction of a fictive East by the West as a kind of inverted mirror. Said argued that this Orient is more related to Western epistemological assumptions and imperialist projects than with the Eastern world itself, its diversity and history. In the same direction, Trouillot discussed the dangers of treating Haiti as a historical and sociocultural exception, an interpretation that has its roots in analyses, especially those of foreign intellectuals and travelers, who emphasized the particularities of the Haitian Revolution (1791-1804) and the idiosyncratic dimension of the country that it formed. Trouillot draws our attention to the fact that Haiti has been seen as an exceptional place, in opposition to the imperialist West and understood as "[its] longest neocolonial experiment" (1990a: 7). From "the first black republic of the Americas" to "the poorest nation in the Western hemisphere" - phrases often present in history books and news throughout the 2oth century - the country is known for its oddness, but can and must also be appreciated for its ordinary dimensions. After all, anthropology teaches us that everyday life and social practices are as relevant as objects of analysis as are major historical events and catastrophes. ${ }^{6}$

The insistence on highlighting supposed Haitian peculiarities also has perverse effects, which both silence the agency of Haitians throughout their history, and minimizes the violent impact of imperialist countries on that history. Moreover, the author revealed how the fiction of Haitian exceptionalism, also produced by Haitian nationalists, gave rise to authoritarian projects of an elite that understood that an exceptional country should be governed in an exceptional way.

\footnotetext{
5 For more details on these works see the introduction of Mello \& Brittes (2018) to the translation of Trouillot (2018) and the reviews of Silencing the Past by Benevides (1999) and, more recently, by Zuker (2019).

6 One cannot forget here the earthquake that shook the country in 2010, leaving some 250 thousand dead and more than one million homeless. The earthquake sparked analyses in the media and academic environments that reinforce the argument of Haitian exceptionalism developed by Trouillot more than a decade earlier. In this sense, see, among others, the article by Thomas (2011) on the earthquake and stigmatizing speech about Haiti.
} 
Thus, the widespread image of a Haiti that is so unique that it is strange or incomprehensible, operates, according to Trouillot as a "shield", which politically isolates the country, preventing its integration into a world "dominated by Christianity, capitalism, and whiteness"(1990a: 7). Thus, Trouillot shows in a number of studies how historical narratives overlap the construction of anthropological images and mechanisms of power that, on different scales, produce inequalities and stigmas. Ending with an invitation to further research, Trouillot anticipates some of the studies that would mark the 2000 s and lays the foundations for a comparative project to understand similar historical processes, which still awaits new contributions.

In his following works, the anthropologist developed a critique of anthropology and its colonialist facet. A demon that still haunts us despite constant efforts to exorcise it, we find in Trouillot's words an important inflection on the possibilities of historicizing social phenomena and the concepts used by historians, philosophers and social scientists. It is not by chance that concepts such as culture, modernity and globalization were provocatively called "North Atlantic universals" by the author (Trouillot, 2003). Through careful critical work with concepts and language throughout his trajectory, Trouillot demonstrated how anthropology could contribute to the renewal of scientific themes, problems and tools.

The republishing of this article, initially prepared for a master class and written amid the turbulence that would lead to the election of Jean-Bertrand Aristide, is an effort to emphasize its power and ability to promote new insights about our contemporary global situation far beyond its undeniable historical, political and spatial roots. It is known that, since its publication, this text was passed from hand-to-hand in photocopies, or scanned and disseminated by generous students, which allowed it to cross hemispheres and seas before the advent of digital archives. The article continues to circulate and inspire researchers who dedicate themselves to the articulations between what Mintz (2012) has famously called Caribbean themes and variations, as well as scholars interested in questioning the classic anthropological opposition between particularism and universalism, articulated by Trouillot through the notion of exceptionalism (Benedicty-Kokken, Byron, Glover \& Schuller, 2016; Bonilla, 2013). Part of a truly critical and engaged work, this text, which was born a classic, now finds a new publication, followed by a translation into Portuguese. We hope that it will circulate more widely and that along with the Portuguese version it joins previous efforts to publicize Trouillot's work in Portuguese-speaking territories and gains new enthusiastic readers and engaged thinkers. 


\section{References}

ANDRADE, Everaldo de Oliveira. 2019. Haiti: dois séculos de história. São Paulo: Alameda.

BENEVIDES, Sérgio Paulo. 1999. "Silencing the past: power and the production of history", Mana, vol. 5, n. 2, pp. 199-201.

BENEDICTY-KOKKEN, A.; BYRON, J.; GLOVER, K.; SCHULLER, M. (Eds.). 2016. The Haiti Exception:

Anthropology and the Predicament of Narrative. Liverpool: Liverpool University Press.

BONILLA, Yarimar. 2013. “Ordinary Sovereignty”, small axe, n. 42, pp. 152-165.

. (2014). "Remembering the songwriter: the life and Legacies of Michel-Rolph Trouillot." Cultural

Dynamics, vol. 26, n. 2, 163-172.

DUBOIS, Laurent. 2012. Haiti: The Aftershocks of History. New York: Metropolitan Books.

. (2013). "Michel-Rolph Trouillot (1949-2012)". Hispanic American Historical Review, 93(4), 685-69o.

GOLDWAY, David. 1986. “Congratulations to Cimarrón!”. Science \& Society, vol. 50, n. 1. p. 127.

HECTOR, Michel; HURBON, Laënnec. 2009. Genèse de l'État haïtien, 1804 - 1859. Paris: La Maison des Sciences de l'Homme.

MELLO, Marcelo Moura; PIRES, Rogério Brittes W. 2018. “Trouillot, o Caribe e a Antropologia”, Afro-Ásia, 58, pp. 189-196.

MINTZ, Sidney. 2012. Three ancient colonies: Caribbean themes and variations. Cambridge:

Harvard University Press.

PRICE, Richard. 2013. “Michel-Rolph Trouillot (1949-2012)”, American Anthropologist, v. 115, n. 4 (2013),

pp. 717-20.

SAID, Edward W. [1978] 199o. Orientalismo: o Oriente como invenção do Ocidente. São Paulo:

Companhia das Letras.

SCOTT, David. 2012. "The Futures of Michel-Rolph Trouillot: in memoriam”, Small Axe: a Caribbean Journal of Criticism, v. 16, n. 3, pp. vii-x.

THOMAZ, Omar Ribeiro. 2011. "Eles são assim: racismo e o terremoto de 12 de janeiro de 2010 no Haiti",

Cadernos de Campo, São Paulo, n. 20, p. 273-284.

TROUILLOT, Michel-Rolph. [1977] 2012. Ti dife boule sou listwa Ayiti. Port-au-Prince: Edisyon KIK, Inivèsite Karayib. . 1981. "Peripheral Vibrations: The Case of Saint-Domingue's Coffee Revolution”. In: RUBINSON, R.

(ed.). Dynamics of World Development, 27-41. Beverly Hills, CA: Sage. . 1982. "Motion in the System: Coffee, Color, and Slavery in Eighteenth-Century Saint-Domingue",

Review 5 (3): 331-388. . 1986. Les Racines Historiques de l'État Duvaliérien. Port-au-Prince: Éditions Deschamps. . 1988. Peasants and Capital: Dominica in the World Economy. Baltimore, MD: Johns Hopkins

University Press. . 1990a. "The Odd and the Ordinary: Haiti, the Caribbean, and the World", Cimarrón: New Perspectives

on the Caribbean, vol. 2, n. 3, pp. 3-12. . 199ob. Haiti, State against Nation: The Origins and Legacy of Duvalierism. New York:

Monthly Review Press. . 1992. "The Vulgarity of Power", Public Culture, vol. 5, n. 1, pp. 75-81. . 1995. Silencing the Past: Power and Production of History. Boston: Beacon Press. 2003. Global Transformations: Anthropology and the Modern World. New York: Palgrave Macmillan. . 2006. "Culture on the Edges: Creolization in the Plantation Context", In: the International Creole Fest (ed.), The African Diaspora and Creolization. Broward County, FL: A.C.T.I.O.N. Foundation, Inc, pp. 9-21, available at http://internationalcreolefest.org/images/CahierICFo6-Booklet.pdf (access: 19/05/2020). 
[1995] 2016. Silenciando o passado: poder e a produção da história. Translated by Sebastião Nascimento.

Curitiba: Huya.

. [1992] 2018. "A região do Caribe: uma fronteira aberta na teoria antropológica". Translated by Marcelo Moura Mello and Rogério Brittes Pires. Afro-Ásia, n. 58, pp. 197-232.

WOODSON, Drexel. “Trouillot, Michel-Rolph”, Encyclopedia of the Social Sciences, Encyclopedia.com., acesso em 13 de maio de 2020, disponível em: https://www.encyclopedia.com. . 2013. "Byen Pre Pa Lakay: Toward a Complete Bibliography of Michel-Rolph Trouillot's", Journal of Haitian Studies, Vol. 19, No. 2, Special Issue on Michel-Rolph Trouillot, pp. 183-202. .; WILLIAMS, Brackette. 2013. "In memoriam: Dr. Michel-Rolph Trouillot (1949-2012)", Caribbean Studies, v. 40, n. 1, pp. 153-62.

ZUKER, Fabio. 2019. “TROUILLOT, Michel-Rolph. Silenciando o Passado", Cadernos de Campo, 28(1), pp. 319-324.

\section{Rodrigo Charafeddine Bulamah}

Graduate Program in Social Sciences, Federal University at São Paulo (Unifesp)

FAPESP Postdoctoral Fellow

https://orcid.org/oooo-0002-4734-7672

Email: rodrigobulamah@gmail.com

\section{Júlia Vilaça Goyatá}

Associate Professor - Department of Sociology and Anthropology, Federal University at Maranhão (UFMA)

https://orcid.org/oooo-0002-3842-1877

Email: julia.goyata@ufma.br

\section{Bethânia Santos Pereira}

PhD student in Cultural History - Graduate Program in History, State University of Campinas (Unicamp)

CNPq fellow

https://orcid.org/o0oo-0001-9493-0062

Email: bethaniapereira21@gmail.com 